\title{
An Inclusive Approach to Care of the Elderly in Bangladesh
}

\author{
Anwara Begum*, Rizwana Islam \\ Senior Research Fellow in the Bangladesh Institute of Development Studies (BIDS), India
}

Submission: July16, 2018; Published: August 15, 2018

"Corresponding author: Anwara Begum, Senior Research Fellow in the Bangladesh Institute of Development Studies (BIDS), Dhaka, Bangladesh, Tel: + 880-02-9143441-8, Fax: + 880-2-8141722, Email: anwarabids@gmail.com

\section{Mini Review}

The care for the elderly is now quite entrenched in most developed countries, with varying intensity; it was both more intensive and extensive in coverage in the earlier socialist countries and is also now more prevalent in countries with more socialistic spirits such as the eastern European and the Nordic countries. The debates on the care for elderly, both from societal perspectives and from the perspective of medical care systems continue in recent literature. In addition to, compared to the most developed countries, old age support program is a newer concept in most developing countries. In addition, Bangladesh's issue of 'care for the elderly' is of recent origin, yet it is limited to care for the public sector retirees, through old age pension system, few rudimentary healthcare supports via public health care system, and few private sectors initiated 'old age homes'. There is no comprehensive policy for systematically developing old age care system. In fact, care for the elderly is something that builds a civilized society with due respect and care for its elderly. It is a way of paying our debts to our mothers and fathers, our parents and grandparents who, left alone, may no longer be able to care for themselves.

Bangladesh, despite the prognosis of a demographic dividend, which some calculate to be optimally effective until 2032 and the longer-term projection being around 2038, is poised to face the growing elderly population (21 per cent) by 2025 and 40 per cent by the middle of this century. For the first time, in 2051, the aged population above 60 years will number more than the 15 years and less, age-groups. Aging is inevitable, and its effect will be of epic proportions upon the income, economy, lifestyle of the active population and the dependent populace. This study was, at core, aimed at assessing the gap between needs and 'current provisions in the country', in care for the elderly, and it was a first-cut assessment, underscoring the need for more studies. The basic objective was to take steps in the right direction in the coming months and years to develop a policy framework for an inclusive approach to care of the elderly. A survey of one hundred and thirty-six respondents has been done as a preliminary assessment, including a sizeable qualitative component from a cross-section of people who are interested, and involved in strategic positions, to benefit this society's aging population.
The quantitative survey respondents' group was proportionately drawn from elderly male-female, also rural-urban areas and reflected the broad income-groups, methodology for which has been elaborated in the main report. It has empirically validated and informed the study on the target beneficiaries who comprise the elderly. And the qualitative opinion assessment has thrown light on the overarching issues and way forward.

The Qualitative Sample comprised of a comprehensive collation of 22 Key Informant Interviews and an Opinion Survey (30 Qualitative Responses) from a cross-section of society. The interviewees included lawyers, private entrepreneurs, community workers, recipients of services, service providers, social welfare officers, youth leaders, health care workers, Fire-Brigade Personnel etc. The recent Parent Care Act of 2013 is unique, as also the National Plans on the Elderly (2006 and 2014). These purport to cater to parent's sustenance, but remain limited in scope, as discussed in the report. Policies and Act remain, effectively inactive. The other programmers such as micro-credit, health, nutrition, population sector programmer, community empowerment, etc. are yet to come into focus about elderly. Findings from the survey reveal that most respondents were in 60-65 age range with some in their early 90s. Most males and females are married. Those males who were widowers, often remarried (higher number of males remarried but few, almost none of the widowed women were remarried). The age gap between male spouse and female spouse was found to be high and thus, more women were widowed and alone. Majority of the respondents were illiterate; A third of the respondents $1 / 3$ earn an income, where males predominate and are residing overwhelmingly in the cities; They suffer from an income deficit ranging from tk. 500 to 10,000 every month; this increases to 12,000 takas in the urban families who experience income deficit. Most who have the resources, have transferred their money and property to their children.

Health problems include eyesight; gout; diabetes, depression; dental; psychological, ailments. Their mental strain emanates from their inability to seek finance their Medicare and aggravated financial constraints lead to psychological depression. For care and service, elders prefer family care; but, 
increasing small families, pose lack of time \& care; Elderly lack govt. health care program and insurance. Situation is worse for the urban residents; elderly females live with relatives and they often suffer immobility and they are abused because of food, money and inability to do house-hold chores. Policy recommendations include the need to keep a provision of adequate budget for the development of elders. There is also a strong call for review (to gauge effectiveness) of the government policies for a more enabling condition-to assess the efficacy of existing programmers and whether they are headed in the right direction, particularly in the light of the National Social Security Strategy (NSSS). The NSSS 2015 has furnished guidelines on Social Security for People with Disabilities. Besides the two groups targeted for "Child Disability Benefit" (all children with a disability, up to 18 years of age), and "A Disability Benefit" for all adults with severe disabilities, aged 19-59 years, there is no provision for disabled old people. It lays down that at 60 years, people with severe disabilities will transition to the Old Age Allowance.

Thus, despite the projected schemes, there remain important challenges to the implementation of the Strategy. Several studies point out that there are sizeable inclusion and exclusion errors, lack of gender targeting, thin dispersal of resources, and program weakness in the current structures of the SSN Programmes, which require attention prior to closure: a fact that must be considered by the NSSS and implementing agencies. The empirical findings reveal that elderly are in satisfactory condition in the context of Bangladesh, where there is still respect for them. This is especially true for those who are in the middle and higher income groups. Elderly people among low income families, or alone/single, who are extremely poor, find their existence, hard. There is a rural-urban, male-female distinction in the attitude, way-of-life of the elderly in Bangladesh. With growing nucleated families, breakdown of joint families, the issues of care for elderly is assuming noticeable proportions especially among the poorer sections and in urban areas. Majority of elderly people suggest that the old age allowance from government has to be enhanced and the magnitude of beneficiaries must be all encompassing and more inclusive.

Study has provided current data on the newly emerging needs and condition of the aged and youths, especially in view of taking advantage of the returns from population dividend that prevails in Bangladesh. Attitudes and perceptions are changing but needs of the poorer sections are becoming more acute, especially with regard to health care. Government should increase outdoor service units in government hospitals and special “Senior Citizens' Card”, could be made available, so that they may avail of free transport services, in addition. To ensure good health and ensure a caring attitude, there is a need to ensure home-based and institute-based health care centers where the elderly would receive proper nursing and care. There should be free help provisions for the elderly in government hospitals as well as other established health care centers. Moreover, the elderly themselves should be educated in self-care. Creating and increasing new space to accommodate scope of work for the elderly who are willing and capable, is now needed. A "National Network of Elderly Persons", could facilitate interaction among the elderly and their care givers, including community members who want to be active in social work, in addition, involvement of industrialist and philanthropists etc.

\section{Your next submission with Juniper Publishers will reach you the below assets}

- Quality Editorial service

- Swift Peer Review

- Reprints availability

- E-prints Service

- Manuscript Podcast for convenient understanding

- Global attainment for your research

- Manuscript accessibility in different formats

( Pdf, E-pub, Full Text, Audio)

- Unceasing customer service

Track the below URL for one-step submission https://juniperpublishers.com/online-submission.php 